Intending Scotland 
For Conan 


\title{
INTENDING SCOTLAND
}

\section{Explorations in Scottish Culture since the Enlightenment}

\author{
Cairns Craig
}


(C) Cairns Craig, 2009

Edinburgh University Press Ltd

22 George Square, Edinburgh

www.euppublishing.com

Typeset by the Research Institute for Irish and Scottish Studies, University of Aberdeen

Printed and bound in Great Britain by CPI Antony Rowe,

Chippenham and Eastbourne

A CIP record for this book is available from the British Library

ISBN 9780748637133 (hardback)

The right of Cairns Craig

to be identified as author of this work

has been asserted in accordance with

the Copyright, Designs and Patents Act 1988

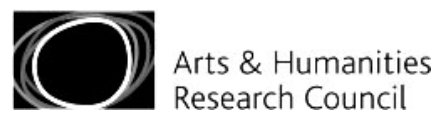

Some of the research contained in this title was supported by the Arts and Humanities Research Council through the AHRC Centre for Irish-Scottish Studies,

University of Aberdeen 